ISSN: $1412-4734$

E-ISSN: 2407-8646

Volume 18, Number 2, 2018

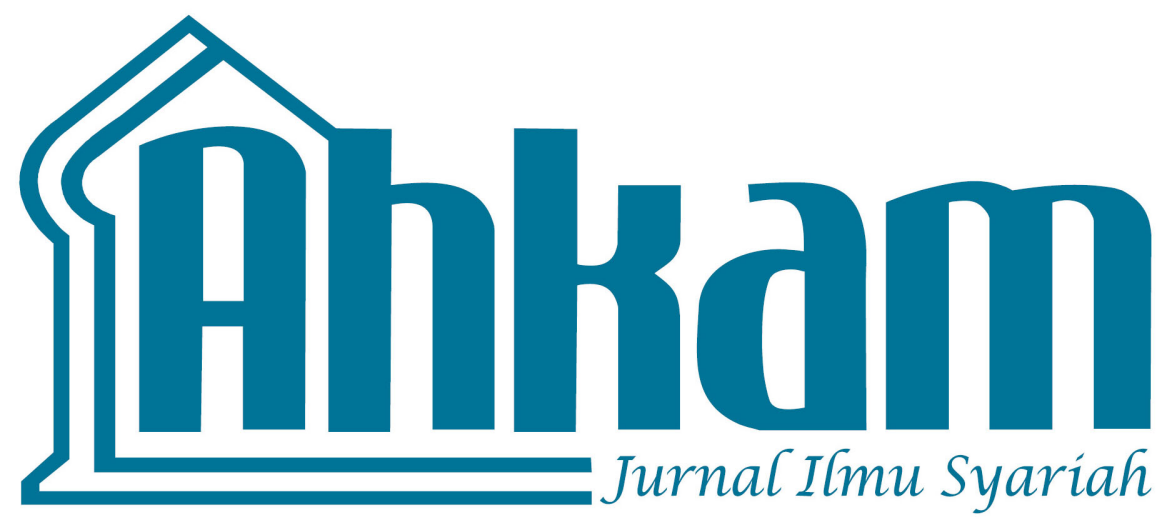

* Arifuddin Muda Harahap

Rules on Wage Standard to Improve Workers' Living Needs in the Perspective of Maqasid Al-Shari'ah

* M. IkHsan TanggoK

Circumcision Law in Christianity and Islam

* Abdul Rohman Zulfikar Alfaroug \& Nurhasanah The Positivisation of National Sharia Board Fatwa About Mudaraba into Financial Service Authority Regulation

* Muhamad Isna Wahyudi

Women Dealing With the Law in Religious Courts

* Arif Hidayatullah \& Anita Priantina

Toward Zakat Management Integration in Indonesia: Problems and Solution

* Muhammad Adil dan Muhamad Harun

Fiqh Melayu Nusantara in the Palembang Darussalam Sultanate Period

* Sugiri Permana

Implications of Hazairin and Munawir Sjadzali Thoughts in Establishment of Islamic Inheritance in Indonesia 


\section{Mhliam}

Volume 18, Number 2, 2018

\section{EDITOR-IN-CHIEF}

Khamami Zada

\section{EDITORS}

Fathudin

Maman R Hakim

Windy Triana

Nur Hidayah

Ahmad Bahtiar

\section{INTERNATIONAL EDITORIAL BOARD}

Tim Lindsey (University of Melbourne Australia)

Nadirsyah Hosen (Monash University Australia)

Ahmad Hidayat Buang (Universiti Malaya Malaysia)

Raihanah Azahari (University Malay Malaysia)

Mark Elwen Cammack (Southwestern University)

Razeen Sappideen (University of Western Sydney)

Carolyn Sappideen (University of Western Sydney)

Nik Ahmad Kamal bin Nik Mahmod (International Islamic Universiti Malaysia)

Ahmad Tholabi Kharlie (UIN Syarif Hidayatullah Jakarta)

Muhammad Atho Mudzhar (UIN Syarif Hidayatullah Jakarta)

Masykuri Abdillah (UIN Syarif Hidayatullah Jakarta)

Muhammad Amin Suma (UIN Syarif Hidayatullah Jakarta)

M. Arsykal Salim GP (UIN Syarif Hidayatullah Jakarta)

Asep Saepudin Jahar (UIN Syarif Hidayatullah Jakarta)

ASSISTANT TO THE EDITORS

Kamal F. Musa

Erwin Hikmatiar

ENGLISH LANGUAGE ADVISOR

Bradley Holland

Umi Kulsum

ARABIC LANGUAGE ADVISOR

Amany Burhanudin Lubis

AHKAM has been accredited based on the determination of Director General of Research Reinforcement and Development, Research, and Technology Ministry of Higher Education of Republic of Indonesia, No. 36/a/E/KPT/2016 (valid until 2021). 
AHKAM Jurnal Ilmu Syariah (ISSN: 1412-4734) is a periodical scientific journal published by Faculty of Sharia and Law of Syarif Hidayatullah State Islamic University Jakarta in collaboration with Indonesian Scientist and Sharia Scholar Association (HISSI). This journal specifically examines the science of sharia and obtains to present various results of current and eminence scientific research. The administrators receive articles as contributions Sharia and Islamic law disciplines from scientists, scholars, professionals, and researchers to be published and disseminated.

\section{EDITORIAL OFFICE:}

Fakultas Syariah dan Hukum UIN Syarif Hidayatullah Jakarta

Jl. Ir. H. Juanda 95 Ciputat, Jakarta 15412

Telp. (+62-21) 74711537, Faks. (+62-21) 7491821

Website: http://journal.uinjkt.ac.id/index.php/ahkam/index

E-mail: Jurnal.ahkam@uinjkt.ac.id 


\section{TABle of Contents}

251 Arifuddin Muda Harahap

Rules on Wage Standard to Improve Workers' Living Needs in the Perspective of Maqasid Al-Shari'ah

265 M. IkHSAN TANGgOK

Circumcision Law in Christianity and Islam

285 Abdul Rohman Zulfikar Alfaroug \& Nurhasanah The Positivisation of National Sharia Board Fatwa About Mudaraba into Financial Service Authority Regulation

305 Muhamad Isna Wahyudi

Women Dealing With the Law in Religious Courts

321 Arif Hidayatullah \& Anita Priantina

Toward Zakat Management Integration in Indonesia:

Problems and Solution

347 Muhammad Adil \& Muhamad Harun

Figh Melayu Nusantara in the Palembang Darussalam Sultanate Period 
375 Sugiri Permana

Implications of Hazairin and Munawir Sjadzali Thoughts in Establishment of Islamic Inheritance in Indonesia

395 RifQi QOWIyul ImAn

The Competence of Religious Court in Indonesia and

Syahadah Istifadhah (Testimonium De Auditu) in Case of Itsbat Waqf

417 Mustapa Khamal Rokan \& Kama Rusdiana Configuration of Costomary Law Related to Economy (Economic Adat Law Study in North Sumatera, Indonesia)

433 Yayan Sopyan \& Muhammad Shofwan Nidzami Nyabek Toloh Marriage Proposal Tradition in Madurese Culture: A Review of The Sociology of Islamic Law

453 Nuryani \& M. Musyafa

Linguistic Review on Marriage Age Regulation

463 Wetria Fauzi

Regulation of Sharia Insurance After the Enactment of Law No. 40 of 2014 Concerning Insurance 


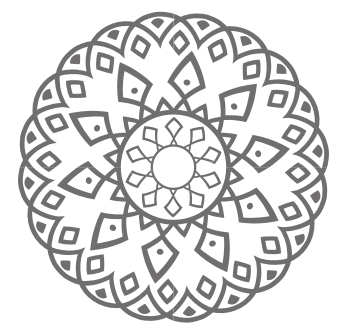

\title{
Women Dealing With The Law In Religious Courts
}

\author{
Muhamad Isna Wahyudi
}

\begin{abstract}
Abstrak: Pengadilan Agama di Indonesia yang memiliki kewenangan khusus mengadili sengketa antara orang-orang yang beragama Islam, merupakan lembaga yang terlibat langsung dengan masalah perempuan berhadapan dengan hukum. Sebagian besar perempuan di Indonesia mencari keadilan di pengadilan agama. Oleh karena itu, penting untuk membahas penerapan perspektif keadilan dan kesetaraan gender di pengadilan agama yang melibatkan perempuan yang berhadapan dengan hukum. Dengan menggunakan perspektif keadilan dan kesetaraan gender, penulis membahas beberapa isu penting yang mencakup perceraian, saksi perempuan, perkawinan anak, harta bersama, poligami, hak asuh anak, pengingkaran anak dan asal-usul anak. Pembahasan ini penting untuk memberikan pedoman bagi para hakim pengadilan agama dalam menerapkan PERMA No. 3 Tahun 2017 tentang Pedoman Mengadili Perkara Perempuan Berhadapan dengan Hukum.
\end{abstract}

Kata kunci: keadilan, kesetaraan gender, dan perempuan berhadapan dengan hukum 
Abstract: Religious Courts in Indonesia which have special jurisdiction to hear disputes among Muslims are directly involved with the issue of women dealing with the law. Most of the Indonesian women seeking justice in religious court. Hence, it is important to discuss the application of justice and gender equality perspective in religious courts involving women dealing with the law. Employing justice and gender equality perspective, the author discusses some crucial issues including divorce, female witness, child marriage, joint property, polygamy, child custody, child denial, and paternity. It argues that such discussion is important as guidance to judges of religious courts in applying Supreme Court Regulation (PERMA) No. 3/2017 on Guidelines for Hearing the Case of Women Dealing with the Law.

Keywords: justice, gender equality, women dealing with the law

$$
\begin{aligned}
& \text { ملخص: والمحاكم الدينية في إندونيسيا التي تتمتع باختصاص خاص للنظر في النزاعات }
\end{aligned}
$$

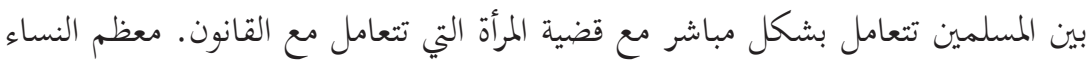

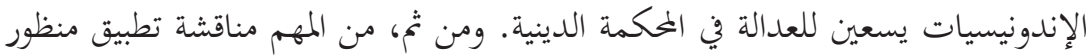

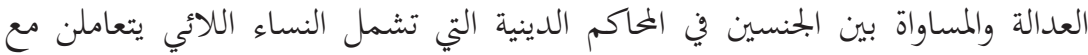

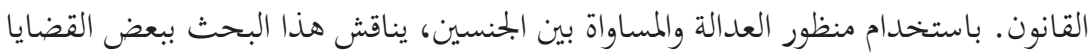

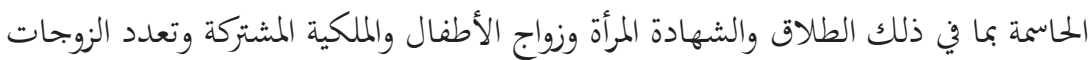

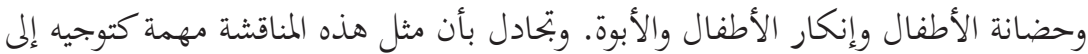

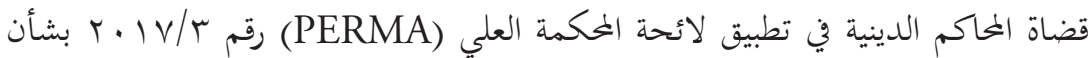

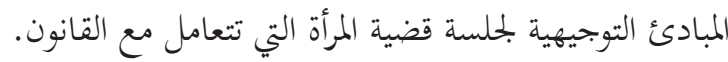$$
\text { الكلمات المفتاحية: العدالة والمساواة بين الجحنسين، والمرأة التي تتعامل مع القانون }
$$ 


\section{Introduction}

Supreme Court of Indonesia has issued Supreme Court Regulation (PERMA) No. 3/2017 on Guidance for Hearing the Case of Women Dealing with the Law. The regulation based on the principle of respect to human dignity, non-discriminative, gender equality, equality before the law, justice, usefulness, and legal certainty. It aims at guiding judge to understand and apply those principles, to identify the unequal treatment that has led to discrimination against women, to guarantee women's rights to equal access in achieving justice.

Religious Courts as one of the courts in Indonesian justice system are directly involved with the issue of women dealing with the law. As a country with the largest Muslim population, most of Indonesian women seeking justice in religious courts. Hence, it is important to discuss the application of justice and gender equality perspective in religious courts involving women dealing with the law on the cases of divorce, female witness, child marriage, joint property, polygamy, child custody, child denial, and paternity

This paper will discuss how the application of justice and gender equality perspective to various crucial issues related to women dealing with the law in religious courts. This paper starts with the discussion on the development of gender discourse in Indonesia followed by a discussion on crucial issues related to women dealing with the law in religious courts.

\section{Gender Discourse in Indonesia}

Gender is generally used to identify differences between men and women in terms of socio-cultural, whereas sex is used to identify the men and women in terms of biological anatomy. In the meaning that gender is not a biological category that is related to the number of chromosomes, the genetic pattern, genital structures; it is a social and cultural construction, which is not irreversible, while sex is nature that is permanent and can not be changed.

Problems arise when there is a mix of gender and nature (sex). Gender involves several key assumptions: (i) gender concerns the position of men and women in society; relationship of men and women is socio-cultural construction, and not biological-natural construction; 
(ii) socio-culturally, the relationship takes the form of male dominance and female subordination; (iii) the division of labor and social distinctions often naturalized (considered "nature") through the myths and religious ideology; (iv) gender is regarding stereotypes of feminine and masculine.

Biological differences between men and women actually do not create problems. That a woman must be pregnant, giving birth, and breastfeeding is natural in accordance with her nature. A new problem arises when the gender differences will give rise to injustice social treatment between men and women. For example, women are positioned as being only allowed to work in the domestic sphere and not in the public sphere because the public sphere is regarded as a special area for men.

The above problem has issued two major theories, namely, nature and nurture. The first theory, nature, states that differences in the roles of men and women are determined by biological factors. Anatomy of male biology with a series of differences with women becoming a major factor in determining the social roles of the sexes. The second theory, nurture, states that the difference in social roles of men and women are determined by cultural factors. According to this theory, the division of the roles of men and women in society is not determined by biological factors, but actually culturally constructed.

At the present time, gender issue is a widespread phenomenon that attracts attention from many elements including women activists, academicians, intellectuals, scholars, professionals, and even men and society in general. Along with the rapid advancement of human thinking and behavior, more people criticize various gender inequalities experienced by women over the years, both in the domestic sector and the public sector.

Muniarti, an Indonesian feminist-theologian, explained periodization of Indonesian women's movement that includes seven periods. The latest is the period between 1998 and now, an inclusive internationally-networked national movement toward gender justice through the improvement of women's knowledge in various aspects of community life.

In Indonesia, the fight against gender inequality issues by the feminist movement, according to Fakih, can be divided into three 
stages decade. The first decade is the stage of "harassment". During 1975-1985 almost all NGO activists considered gender issues was not an important issue, even many who did harassment. The second period was from 1985 to 1995 decade. The decade was basically a decade of recognition and understanding of what constituted gender analysis and why gender became an issue of development. In this second decade, challenges to patriarchal-thought and religious interpretation emerged, so that studies on the gender-bias religious teachings were necessary. And the last period of the decade working to integrate gender into all policies and programs of various organizations and educational institutions, as well as advocacy of gender equality on the substance, culture, and structure of the unjust laws according to a gender perspective.

In addition, since 1984, Indonesia has ratified CEDAW (Convention on the Elimination of All Forms of Discrimination Against Women) through Act No. 7/1984, on July 24, 1984, and promulgated by the State Gazette No. 29/1984 as well as the explanation in the State Gazette No. 3277. As a consequence, there is a demand for the Indonesian government to make corrections to various laws and regulations if it is proven to be discriminative against women.

In connection with gender inequality, ironically, the most highlighted and accused by many people as the source of this injustice is the existence of religions. Religion has been used as a tool to legitimize gender inequality of women to men. In fact, religion that promotes universal principles, such as justice and equality of human dignity. Such conditions certainly require reform of religious understanding, so that enabling to embody the principles of Islamic egalitarianism in the relationship between men and women.

\section{Some Crucial Issues on Women Dealing with the Law in Religious Courts}

\section{Women and Divorce}

M. Syaifuddin and Sri Turatmiyah, based on the research in the Religious Court of Palembang, find some obstacles for wives who file divorce to the court, including: first, threat or intimidation on the part of the husband, where most women are afraid of actors mostly is the husband of the victim; second, it concerns self-esteem in people's lives because if the wife sues for divorce, the image in society is not good; third, 
cultural factors, people are still viewing divorced women negatively; fourth, the great economic dependency on the husband makes women feel powerless to support herself; fifth, a minimal knowledge of the proceedings, division of joint-property, custody of children, and others; sixth, judge's bias perspective and tendency to blame women in dealing with the case of divorce initiated by wife; seventh, a long trial process and the specific costs of the victim; eighth, women being surrender to accept any circumstances include any form of treatment, for example the fact of physical and mental violence carried out by her husband in the household; ninth, women do not have awareness of their rights and are not confident to their existence and competence if they want to divorce in court; tenth, the court acknowledges that it has no power to pressure the ex-husbands in order to carry out their legal obligations.

Related to the first obstacle, namely the existence of threats or intimidation on the part of the husband, women who deal with the law in religious courts require assistance during the proceedings, or may claim to live separately with her husband during the proceedings. Cases of stabbing wife by the husband in a religious court also need to be anticipated by screening to any visitor from bringing dangerous goods, and more adequate trial security.

Regarding the lack of knowledge about the proceedings and the rights of the wife due to divorce, the judge can give an explanation in the court hearing concerning these matters. In case of wife does not demand her rights arising from divorce initiated by the husband (cerai talak), the judge can also use his/her position (ex-officio) to sentence the husband to provide his wife's rights after divorce, including child support if the child is under the custody of his wife.

Related to the biased-perspective of the judges and tendency to blame women in addressing the issue of divorce initiated by wife, the judges need to maintain impartiality in the court hearing. The impression of gender bias and blaming women in divorce often appear in the reconciliation efforts conducted by the judges in the court hearing. Therefore, the choice of words in reconciliation or advisory efforts by the judges should maintaine the principle of impartiality and in line with the perspective of gender justice and equality.

In terms of barriers relating to poverty and court fees, women 
can use the service of waiving court fees for the poor from the court. Meanwhile, to get assistance when women are incompetent to be litigants during the proceedings, women may have the service of legal aid post (POSBAKUM) in court funded by the state under the Ministry of Law and Human Right. This service covers the lawyer's cost to assist those who are incompetent during the proceedings in court.

Related to an effective and efficient mechanism to pressure exhusbands to meet their obligations including maintenance during the waiting period (nafkah iddah), consolation gift (mutah), child support, is still a problem. In practice, the judge will postpone talak pronouncement from the husband if the husband has not been ready to meet the obligations imposed, while the wife does not want if the obligations will be paid later because there are no guarantees from the husband to meet his obligations. The effort has been proven quite effective, at least in the Religious Court of Bima where the author works now. In order to provide protection to women's rights following the divorce, the Supreme Court has accommodated the practice in Supreme Court Circular No. 1, 2017, that instructs judges to insert an order that the fulfillment of wife's rights following divorce should be paid before the execution of talak pronouncement by the husband.

While related to child maintenance, the routine obligation to provide child maintenance by ex-husband will be difficult to be executed if the ex-husband does not meet his obligation voluntarily due to the repeated execution. In this case, it is necessary to build a network system that enables to ensure the implementation of the fulfillment of postdivorce rights for the widow and children through money withdrawal from the ex-husband's account. This network system has been in force in advanced countries such as Australia. While in Indonesia, the system is still limited to civil servants. When divorce initiated by the husband, he must share his salary with his ex-wife and children, one-third for the husband, one-third for the ex-wife, and another third for the child, as stipulated in Government Regulation No. 10/1983 and No. 45/1990.

In the United States, the enforcement of court decision on child support embraces cross-service and inter-agency integrated mechanism. Parents who neglect and do not guarantee the welfare of children of divorced couples will not get public services. While in Australia, child's post-divorce rights are taken care of by a special commission in court 
called the Department of Human Services-Child-Support. Before the divorce, the commission decides the party who is responsible for child custody and providing child support. If there is no party who is responsible for fulfilling the rights of the child, then the commission will make recommendations to the state agency that would cover the child's necessities.

\section{Women as Witnesses}

Basically, jurists acknowledge the position of woman to be a witness. However, jurists differ on the admission of women's testimony based on the number of witness and subject of the testimony. Based on the number, the value of the testimony of two women are considered to be equal to the value of testimony given by a man, it is in accordance with the Qur'an, Surah Al-Baqarah (2): 282.

In the matter of marriage, jurists differ in terms of the testimony of two women, along with the testimony of a man. According to the Hanafi scholars, the testimony of two women and one man is acceptable in matters relating to civil rights, either property or rights, that do not relate to assets such as marriage, divorce, waiting period, hiwälah, endowment, will, grant, acknowledgment, free of pregnancy (ibra), birth, and lineage. Meanwhile, according to scholars of Shafi'i, Maliki, and Hanbali, testimony of two women and one man is acceptable in matters of assets only and related to property such as the sale and purchase, lease, grant, will, mortgage, and kafälah. The reason of refusing the testimony of women is because women tend to have compassion, their memory is not intact, and the limited role of women in various affairs.

The above reason raises a question whether the weaknesses inherent in women is nature - which can not be changed or gender that influenced by the prevailing culture for women in a certain time? The answer to this question will have implications on the position and the value of the testimony of women. However, before giving an answer to the above question, we need to look back at the history of the Arab community situation when the verse (2: 282) was revealed, particularly with regard to the role of women at the time.

Based on the chronology of the Qur'an according to both 
Islamic and Western scholarship, the verse (2: 282) included in the verse of Madaniyyah, which is revealed after the hijrah of the Prophet Muhammad. It is necessary to know that under customary law prevailed among tribes in Arabia during the advent of Islam, women in Arabia, in general, did not have legal status. They were sold into marriage by their guardian for a price paid to the guardian, their husband could end their marriage as they pleased, and women had little wealth or inheritance rights, or not at all.

In Arab society, the man has the duty to defend and maintain the whole family members, responsible to meet all the needs of the family members. As the consequence, men monopolize the leadership at all levels. Men have more duty in the public sphere, while women serving in the domestic area, taking care of the household and reproductive tasks. Men have more duty outside the home, while women have a duty in or around the house or tents.

Back to the verse (2: 282), then we can see that the text related to the transaction of debt. At that time, because of the restriction of women's roles in the domestic sphere, women were not experienced and familiar with the affairs of debt. Thus it is fair if women's memory is considered to be weak to be the witness in matters which women are rarely to handle. Therefore, it is required the testimony of two women, so that if one of the two forgets, the other will remind her.

Regarding the verse (2:282), Engineer argues that although this verse encourages two female witnesses to represent a male witness, only one of the two women who testifies, while another woman functions to remind the witness if she is in doubt (due to lack of experience in financial matters). Therefore, this verse constitutes contextual verse and not normative verse. The Qur'an does not establish a norm that in matters of testimony, two women are treated as equal to one man. If it is what the Qur'an proposes, in every problem of testimony, the Qur'an will treat women in the same way. While in the Qur'an, there are seven other verses about testimony, but none of the verses stipulating two female witnesses instead of one male witness, namely: Surah Al-Māidah (5):106,107; Surah An-Nisâ` (4):15; Surah An-Nûr (24): 4, 6, 8; Surah At\}-T\}alâq (65): 2.

While Wadud argues that, according to the wording of the verse, the two women are not called both as witnesses, because one woman is 
appointed to 'remind' another woman, she acts as a friend of cooperation (collaborator), although there are two women, but each woman has a different function, and the verse is specific to the financial agreement, and is not intended to be generalized, or does not apply to other issues.

Based on the above discussion, the reasons relied upon the testimony of a women is equal to a half of the testimony of a man, such as women are considered to often forget, tend to have compassion, and the limited role of women in various affairs, seem to be the influence of the prevailing culture to women in the early time of Islam in Arabia when women's role was restricted to domestic sphere, so that they were not familiar with the problems in the public sphere. Such a situation would reduce their competence when they asked to give testimony related to matters in the public sphere. While at this time, along with the social changes in society that allow women to jump in and play a role in various public affairs, including to obtain higher education, working in various sectors of employment, even to serve as head of state, the provision that woman is forgetful so that her testimony is equal to a half of that of a man needs to be reviewed. The provision is actually temporal and not universal.

\section{Women and Child Marriage}

Social-culture in terms of child marriage is influenced by the values believed by the public. For Muslim community, in case of child marriage, indeed there is a hadith narrated by Hisham ibn 'Urwah, which is often used as a basis/proposition on the permissibility of child marriages, which tells us that Aisha was married to the Prophet at the age of 7 years old, and began to have sex with Prophet at the age of 9 years.

However, Hisham ibn 'Urwah's account can not be used as proof because it is contrary to many other accounts. Moreover, there is no reason to accept the account of Hisham ibn 'Urwah as valid, while other scholars, including Malik ibn Anas who views the account of Hisham ibn' Urwah during in Iraq, as untrustworthy. Accounts from Tabari, Bukhari and Muslim show their contradictory with each other regarding Aisha's age. Moreover, many of these scholars who are contradictory to themselves in their own account. Thus, the history of Aisha's age at marriage cannot be trusted because of the contradictions 
appeared in the works of classical Islamic scholars. Therefore, there is no reason to believe that information about the age of Aisha is accepted as true when there is sufficient reason to reject it as a myth.

Besides the influence of understanding on the above religious norms, the culture in a society that encourages child marriage is due to cultural values to preserve family honor. In the sense that family will maintain the honor by controlling girls from doing embarrassing act that resulted in the damage of family honor. For example, when the girl has a close relationship with a man, to prevent pregnancy out of wedlock, the family will soon marry the girl with the man. Pregnancy out of wedlock is a shame/embarrassment (sirik) for families in the community such Makassar.

Other values to maintain the honor of the family such as if the family has a daughter who is old enough, but she has not been married yet, it is considered that the daughter is not salable. Moreover, in a society where the custom of selarian/selariang still prevails, in which the girl agrees with her male partner to be taken away due to the absence of agreement on the money of marriage with the woman's family, her family will tend to marry the girl, otherwise it would disgrace the family.

In case of the petition for marriage dispensation, the impact of marriage for a female child who is aged under 16 years, both in terms of education, psychology, social, economic, and reproductive health should be a major consideration for the judges besides the motives of parents who request dispensation to marry for the child. In this case, women are vulnerable to experience marital risk higher than men. Moreover, Law No. 1/1974 on Marriage in Indonesia allows child marriage for girls by stipulating the minimum age of marriage for women is 16 years.

\section{Women and Joint-Property}

Working as the housekeeper for women is often considered as natural and has lower appreciation because it does not get income. As a result, in dealing with the case of joint property, the legal reasoning in the division of joint property based more on who does more to get the joint property. Domestic role of women in taking care of the household 
to maintain a balance in the family - when men have to spend most of the time to work outside the home to earn money - is neglected. Based on the perspective of justice and gender equality, women's domestic role deserves proper estimation in terms of the division of joint property.

The division of joint property with a half for each spouse is in accordance with the sense of justice in terms of both husband and wife play role to maintain the endurance of the family. In this case, the consideration that the spouse is entitled to half of the joint property is based on the role played by either the husband or wife, as a complementary partner in order to maintain the endurance of the family.

In this case, the role of the spouse is not understood based on sex and role standardization, that the husband as breadwinner while the wife as housekeeper. In case of the husband does not work, but he still has a major role in maintaining the endurance of the family, such as taking care of domestic affairs, dropping off and picking up the kids and wife, even shopping and providing for eating and drinking, while the wife works, the husband is still worth to get right half of the joint property. Although the husband does not work to have income, by maintaining children and doing the housework, the wife has received valuable assistance that greatly affects the completion of her daily works and resulted in the amount of income obtained.

Conversely, when the wife is working, while the husband does not play the proper role as a partner to maintain the continuity of the family, division of joint property a half for each spouse is contradictory to the sense of justice. In this case, the wife should have more than the husband. In this case, the principle of "sakgendong sakpikul" can be adopted as one option, but its application is reversed, in the sense that the wife gets two-thirds of the joint property and the husband get onethird. Even when the husband during the marriage is wasteful, gambler and drunkard, the husband should not obtain the right to the division of joint property.

\section{Women and Polygamy}

One of the requirements to obtain the permit of polygamy from a religious court is consent from the wife. The wife's consent should 
be delivered in person in the court hearing, and not merely a letter of statement of the wife. It is important to note in order to avoid fraud on the part of the husband. In addition, with the presence of a wife in the court hearing, the judge can find the reasons of the wife to permit her husband to remarry. Normally, there is certainly no wife who wants to be a co-wife. However, a wife is often in a state of helplessness to make any choice in cases of polygamy, for several reasons. First, the high economic dependence on the husband, in case the wife does not have a job so that she does not have income independently. Second, genderbiased and discriminative religious understanding against women due to the influence of patriarchal culture. Third, threats or intimidation on the part of the husband if the wife does not allow her husband to remarry. The judge should have gender sensitivity by examining these reasons in dealing with the cases of polygamy.

\section{Women and Child Custody}

Gender inequality in dealing with the case of child custody in religious courts relied on at least two reasons that make child custody shift from mother to the father. First, as a working mother. In this case, a working mother considered having no time to care for children, while a working father is considered as a common matter, although children will also be cared for temporarily by the family of the father, the same thing that experienced by the working mother. Differentiation of role, that a woman's main role is in the domestic sphere, and a man's main role is in the public sphere, has led to bias.

Second, the conversion of mother and the different faith of the mother's families. In this case, worrying about the conversion of the child becomes the primary consideration than the consideration of the best interests of the child. Protection of child's religion is regarded to represent the fulfillment of the best interests of the child, regardless of consideration on child's age, level of child dependency, and the proximity of the child with his mother. The conversion of the child is actually a stereotype that may not be proven to occur. Indeed, in this case, religious affiliation may lead to bias and partiality in dealing with the dispute on child custody. 


\section{Women and Child Denial}

If the reason for divorce because of lian, namely the husband accuses his wife for committing adultery or denies the child in the womb of his wife or that has been born from his wife, while the wife rejects the accusation and/or the denial, in order to protect wife from the husband's arbitrariness, as far as possible the reasons argued by the husband must be proven by the husband, before employing oath evidence, as regulated in Article $127 \mathrm{KHI}$ and Article 87 of Law No. 7/1989. In relation to the denial of the child, the husband must be able to prove through DNA test, which is a perfect evidence in proving the origin of a child. This is in accordance with Article 44 of Law No. $1 / 1974$. In cases of divorce, the husband usually denies a child to escape from the responsibility of child support.

Li'an that requires an oath only, needs to be understood as an institution that emerged in a society with patriarchal culture in the early Islamic period in Arabia. The imposition of an oath in the case of li'an at the time was a progressive effort to protect the wife from the husband's arbitrariness. The social structure at that time considered the position of men is higher than the position of women. As a result, husbands tend to abuse against wives, including denial of the child born by his wife as the reason of divorce, to avoid the responsibility for the child. Oath becomes the final evidence when it is almost impossible to impose on the husband to bring DNA test as evidence at the time. Such a situation is applicable in the context of family law and not in the context of criminal law.

\section{Women and Child Parentage}

To realize the decision of the Constitutional Court Number 46/PUU-VIII/2010 on 13 February 2012 regarding the status of a child born out of wedlock, women still need to file a petition for the determination of child parentage. In case the man as the child's biological father is reluctant to file the petition, the case becomes a lawsuit in which the man's as the defendant. By determination of child parentage, it can be known the biological father of the child born out of wedlock based on natural blood relationship that can be used as the basis for the child to obtain civil rights from his/her biological father and his/her father's relative. Based on a court decision, the status of an 
illegitimate child will be registered as the child of a mother and a father in the birth certificate.

\section{Conclusion}

Discussion on some crucial issues related to women dealing with the law in this paper aims at providing guidance to judges of religious courts in applying Supreme Court Regulation (PERMA) No. 3/2017 on Guidelines for Hearing the Case of Women Dealing with the Law.

Understanding the justice and gender equality perspective becomes a necessity for the judges in hearing cases of women dealing with the law. Gender sensitivity is absolutely needed by the judges in order to embody justice for women dealing with the law while maintaining impartiality and preventing from gender bias.[]

\section{References}

Ali, Shaheen Sardar, Gender and Human Rights in Islam and International Law: Equal before Allah, Unequal Before Man? The Hague/London/Boston: Kluwer Law International, 2000.

Amal, Taufik Adnan, Rekonstruksi Sejarah Al-Qur'an, $1^{\text {st }}$ Edition, Jakarta: Pustaka Alvabet, 2005.

Antonio, Muhammad Syafii, Muhammad SAW: The SuperLeader Super Manager, $8^{\text {th }}$ Edition, Jakarta: Tazkia Publishing \& ProLM Centre, 2008.

Az-Zuhaylī, Wahbah, Al-Figh al-Islämiy wa Adillatuhu, $3^{\text {rd }}$ Edition, Damaskus: Dār al-Fikr, 1409 H/1989 M, juz VI.

Coulson, Noel and Doreen Hinchcliffe, "Women and Law Reform in Contemporary Islam," in Women in the Muslim World, editor: Lois Beck and Nikkie Kiddie (Cambridge, Massachussett, and London, England: Havard University Press, 1978.

Engineer, Asghar Ali, Hak-Hak Perempuan dalam Islam, trans. Farid Wajidi and Cici Farha Assegaf, Yogyakarta: LSPA, 2000.

Fakih, Mansour, Analisis Gender \& Transformasi Sosial, 9 ${ }^{\text {th }}$ Edition, Yogyakarta: Pustaka Pelajar, 2005.

Hidayatullah, Syarif, "Gender and Religion: An Islamic Perspective," Al-Jämiah, Vol. 39, No. 2 (2001), p. 324-340.

Majalah Peradilan Agama, Edisi IX, April 2016.

Majalah Peradilan Agama, Edisi VI, Mei 2015.

Muniarti, A. Nunuk P., Getar Gender, Buku Pertama, Magelang: Indonesia Tera, 2004. 
Nasution, Khoiruddin, "Fiqih Islam Sekitar Wanita, Antara Skripturalis dan Kontekstual, " paper presented in conference Reading the Religious Texts and The Roots of Fundamentalism, at Saphir hotel, Jogjakarta, 13 Juni 2004.

Rahman, Fazlur, Tema Pokok Al-Qur'an, trans. Anas Mahyuddin, Bandung: Pustaka, 1983.

Said, Nur, Perempuan Dalam Himpitan Teologi dan HAM di Indonesia, $1^{\text {st }}$ Edition, Yogyakarta: Pilar Media, 2005.

Salenda Kasjim, "Abuse of Islamic Law and Child Marriage in South-Sulawesi Indonesia," in Al-Jamiah: Journal of Islamic Studies, Vol. 54, No. 1, 2016 M, p. $95-122$.

Shanavas, T.O., Was Ayesha A Six-Year-Old Bride? The Ancient Myth Exposed, $<$ http://www.iiie.net/index.php?q=node/58>.

Syaifuddin, M. and Sri Turatmiyah, "Perlindungan Hukum Terhadap Perempuan dalam Proses Gugat Cerai (Khulu') di Pengadilan Agama Palembang, " in Jurnal Dinamika Hukum, Vol. 12 No. 2, Mei 2012, p. 248-260.

Tucker, Judith E. (ed.), Arab Women, Bloomington \& Indianapolis: Indiana University Press, 1993.

Umar, Nasaruddin, Argumen Kesetaraan Gender Perspektif Al-Qur'an, $1^{\text {st }}$ Edition, Jakarta: Paramadina, 1999.

Wadud, Amina, Qur'an and Woman: Rereading the Sacred Text from a Woman's Perspective, New York: Oxford University Press, 1999.

Muhamad Isna Wahyudi, Religious Court of Bima. Email: isnawahyudi@gmail.com 


\section{Mhliam}

AHKAM Jurnal Ilmu Syariah (ISSN: 1412-4734/E-ISSN: 2407-8646) is a periodical scientific journal published by Faculty of Sharia and Law of Syarif Hidayatullah State Islamic University Jakarta in collaboration with Indonesian Scientist and Sharia Scholar Association (HISSI). This journal specifically examines the science of sharia and obtains to present various results of current and eminence scientific research. The administrators receive articles as contributions Sharia and Islamic law disciplines from scientists, scholars, professionals, and researchers to be published and disseminated. The article will be situated in a selection mechanism, a review of proved reders, and a strict editing process. All articles published in this Journal are based on the views of the authors, but they do not represent the authors' journals or affiliated institutions.

AHKAM has been accredited based on the determination of Director General of Research Reinforcement and Development, Research, and Technology Ministry of Higher Education of Republic of Indonesia, No. 36/a/E/KPT/2016 (valid until 2021). 